Article

\title{
Firm Size and Sustainable Innovation: A Theoretical and Empirical Analysis
}

\author{
Luigi Aldieri * (1) and Concetto Paolo Vinci \\ Department of Economic and Statistical Sciences, University of Salerno, 84084 Fisciano, Italy; cpvinci@unisa.it \\ * Correspondence: laldieri@unisa.it
}

Received: 20 April 2019; Accepted: 9 May 2019; Published: 15 May 2019

\begin{abstract}
This paper explores the relationship between firm size and sustainable innovation in large international firms. To this end, we develop a labor demand framework. The contribution to the literature is to explore external knowledge in determining the employment impact of sustainable innovation. Our investigation is based on firms in three economic areas: Europe, Japan, and the United States. In this way, we will appreciate the extent to which the technological spillovers are important from a geographical perspective. The findings provide evidence of the significance of spillover effects on a firm's size; however, these effects depend on the spillover stock type.
\end{abstract}

Keywords: firm size; sustainable innovation; knowledge diffusion process

JEL Classification: O33; J20

\section{Introduction}

The analysis concerning the impact of sustainable innovation on a firm's size in terms of employment is subject to present economic debate [1-3]. Indeed, technological progress represents a quest to reduce labor costs, which is a key sustainable goal in a world of finite natural resources.

There exist many definitions of sustainable innovation in the literature. The idea used in this analysis is in line with the concept introduced by Pezzey [4]: Innovation is sustainable in the sense that the innovation process, contributing to sustainable development, assures that the consumption of the current generation is less than or equal to the maximum consumption of future generations, on the basis of the production opportunities available at present.

Thus, the investigation concerning the impact of sustainable innovations on firms' size is important with regard to increasing production opportunities. The main contribution of our analysis is that we explore the role of external knowledge in the context of sustainable innovation. Indeed, the literature lacks a comprehensive explanation of how the firms adapt their strategies after the innovations, as discussed in Cozzolino et al. [5]. Our analysis attempts to provide this by paying attention to the knowledge diffusion process.

In particular, there are studies that provide evidence of the importance of robotics on firms' size quality, as discussed in Brynjolfsson and McAfee [6,7]. We demonstrate that a reduction of the number of employees to achieve the same production level can result after sustainable innovation (destruction effect), and an increase in the number of employees produced by the new competitive context could derive from sustainable innovation (compensation effect). The effect of sustainable innovation on firm size depends also on the product or process innovation, the elasticity of the market demand of the product with respect to its price, the market power, and wage negotiation. Since theoretical and empirical work in the literature has focused on the internal firm size impact of innovation, this paper deals with the important role of international, national, inter-industry, and intra-industry spillovers in affecting firms' sizes in Europe, Japan, and the USA [8-12]. 
This paper is organized as follows. Section 2 provides a review of the literature concerning the employment effect of sustainable innovation. Section 3 describes the theory. Section 4 explains the methodological approach and the data. Section 5 provides the findings of the investigation. Finally, Section 6 reports and discusses policy implications.

\section{Literature Review}

Empirical studies exist based on the different results of sustainable innovation on firms' sizes in terms of employment [13-15].

Bogliacino et al. [16] consider the impact of innovation in developed countries. Blanchflower and Burgess [17] demonstrate the positive effect of innovation on labor. Brouwer et al. [18] and Zimmerman [19] report a negative effect. There are studies based on German data [19,20], Spanish data [21], and US data [22,23]. Other works outline positive effects of innovation in other developed economies [24-30]. In Ciriaci et al. [31] the job creation process is persistent in innovative firms. There are also empirical studies concerning developing countries [32].

Recent studies investigate the sustainability-oriented innovation process for firms' sizes [33-35]. Indeed, the development of new products or services-which contribute to economic, environmental, and social sustainability—is considered a key element of achieving sustainability. In particular, foreign direct investments help firms in the realization of their sustainable innovation strategies. Thus, this finding demonstrates that the role of the cooperation patterns between the firms is extremely important for full achievement of sustainability. Moreover, it is important to examine all channels of knowledge through absorptive capacity and cooperation, according to size and age. In this economic perspective, our paper tries to shed light on the role of the knowledge diffusion process of sustainable innovations on firms' sizes.

\section{Theoretical Framework}

In this section, we follow the approach in Garcia et al. [36], where a firm competes in the differentiated product market and minimizes costs. The choice of this approach is opportune for sustainability context, because the resources are finite and firms must obtain the production at the lowest cost as possible. In this way, the firms, through the sustainable innovation process, allow the use of resources by future generations [4].

We define the accumulated knowledge capital as $k$, and $w$ and $c$ are the vector inputs prices and the marginal cost, respectively. Thus, we get $c=c(w, k)$ and we denote with $y$ the production, $l$ the firms' sizes in terms of employment, $p$ the output price, $\mu$ the mark-up, $d^{e}$ a measure of the market dynamics, and finally, with $p_{R}, k_{R}$ the rival output prices and firms' accumulated knowledge capital, which represent the knowledge spillovers:

$$
\begin{gathered}
y=y\left(d^{e}, P, P_{R}, k, k_{R}\right) \\
P=(1+\mu) c(w, k) \\
l=c_{L}(w, k) y \\
P_{R}=\left(1+\mu_{R}\right) c_{R}\left(w_{R}, k_{R}\right) \\
k_{R}=g(k)
\end{gathered}
$$

where $w_{R}, c_{R}, \mu_{R}$ denote the inputs prices, marginal cost, and mark-up, respectively. For the other firms, $c_{L}$ measures the derivative of the marginal cost with respect to employment. Once simple computations are made, Equation (4) becomes:

$$
l=c_{L}(w, k) y\left[d^{e},(1+\mu) c(w, k),\left(1+\mu_{R}\right) c_{R}\left(w_{R}, g(k)\right), k, g(k)\right]
$$


From this equation, we can see that the short run impact of innovation on firms' sizes is:

$$
\frac{\partial l}{\partial k}=\frac{\partial c_{L}}{\partial k} y+c_{L}\left\{\frac{\partial y}{\partial k}+\frac{\partial y}{\partial p} \frac{\partial p}{\partial k}+\frac{\partial y}{\partial p_{R}} \frac{\partial p_{R}}{\partial k_{R}} \frac{\partial k_{R}}{\partial k}+\frac{\partial y}{\partial k_{R}} \frac{\partial k_{R}}{\partial k}\right\}
$$

The first term is the displacement effect, while the second is the compensation effect.

If we consider that wages are $w$ and decided by unions, and denote with $z$ and $z_{R}$ other potential changes we can get:

$$
\begin{gathered}
w=w(z, k) \\
w_{R}=w_{R}\left(z_{R}, k_{R}\right) \\
\mu=\mu(z, k) \\
\mu_{R}=\mu_{R}\left(z_{R}, k_{R}\right)
\end{gathered}
$$

Hence, Equation (6) can be written as:

$$
\begin{gathered}
l=c_{L}(w(z, k), k) D\left[d^{e},(1+\mu(z, k)) c(w(z, k), k),(1+\right. \\
\left.\left.\mu_{R}\left(z_{R}, g(k)\right)\right) c_{R}\left(w_{R}\left(z_{R}, g(k)\right), g(k)\right), k, g(k)\right] \\
\frac{\partial l}{\partial k}=\left[\frac{\partial c_{L}}{\partial k}+\frac{\partial c_{L}}{\partial w} \frac{\partial w}{\partial k}\right] y+c_{L} \\
\left\{\frac{\partial y}{\partial k}+\frac{\partial y}{\partial p}\left\{\frac{\partial \mu}{\partial k} c+(1+\mu)\left[\frac{\partial c}{\partial w} \frac{\partial w}{\partial k}+\frac{\partial c}{\partial k}\right]\right\}+\frac{\partial y}{\partial p_{R}}\left[c_{R}\left\{\frac{\partial \mu_{R}}{\partial k_{R}} \frac{\partial k_{R}}{\partial k}\right\}+(1+\right.\right. \\
\left.\left.\left.\mu_{R}\right)\left\{\frac{\partial c_{R}}{\partial w_{R}} \frac{\partial w_{R}}{\partial k_{R}} \frac{\partial k_{R}}{\partial k}+\frac{\partial c_{R}}{\partial k_{R}} \frac{\partial k_{R}}{\partial k}\right\}\right]+\frac{\partial y}{\partial k_{R}} \frac{\partial k_{R}}{\partial k}\right\}
\end{gathered}
$$

Equations (6), (7) and (13) allow us to identify the role of the knowledge diffusion process on firms' sizes, through the impact of external sustainable innovations (knowledge spillovers).

In the subsequent paragraph, we analyze the impact of R\&D spillovers on firms' sizes in terms of employment.

\section{Data}

In our dataset, the information comes from all R\&D investment scoreboards [37]. We combine the most recent scoreboard to avoid multiple counting of the same observations.

We select sales (y), the firms' sizes (l), the capital expenditures (c), R\&D activity (k), and profit (op). The Industrial Classification Benchmark (ICB) measures industrial fields. The data regarding patents are selected from the OECD, REGPAT database [38] (See Maraut, Dernis, Webb, Spiezia and Guellec [39] for the methodology used for the construction of REGPAT database and please contact Helene.DERNIS@oecd.org to download it). We implement the same matching procedure as that described in Aldieri and Vinci [10]. At the final stage, we use an unbalanced panel of 879 firms from 2002 to 2010.

To compute the spillovers components ( $k_{R}$ in theoretical model), we follow Jaffe [40]'s technological index: The sum of R\&D weighted on the correlation index between the distribution vectors of patents relative to domestic firms represents the "national spillovers" (ns); the sum of R\&D weighted on the correlation index between the distribution vectors of patents relative to firms located in different countries is defined as "international spillovers" (is); the weighted sum of R\&D relative to firms operating in the same technological sector is identified as "intra-industry stock of spillovers" (intra-s); and the weighted sum of R\&D relative to firms in other technological fields is associated with "inter-industry stock of spillovers" (inter-s).

Because there are no available data on wages, we introduce operating profit and capital expenditures as proxies, as discussed in Bogliacino [41].

Table 1 shows the statistical features of our variables. 
Table 1. Summary statistics.

\begin{tabular}{|c|c|c|c|c|}
\hline Variables & Mean & Std. Dev. & Skewness & Kurtosis \\
\hline \multicolumn{5}{|l|}{ All samples: 4045 observations. } \\
\hline Employees (l) & 37,012 & 62,600 & 3.443 & 17.437 \\
\hline Sales (y) & 8.02 & 1.676 & -0.244 & 3.190 \\
\hline Capital expenditures (c) & 7.03 & 1.862 & -0.083 & 2.889 \\
\hline Operating profit (op) & 4.96 & 1.945 & -0.011 & 2.908 \\
\hline $\mathrm{R} \& \mathrm{D}(\mathrm{k})$ & 6.56 & 1.486 & 0.275 & 3.255 \\
\hline National Spillovers (ns) & 11.65 & 0.772 & -2.313 & 10.28 \\
\hline International Spillovers (is) & 12.44 & 0.514 & -1.563 & 8.537 \\
\hline Intra-industry Spillovers (intra-s) & 11.86 & 1.146 & -0.533 & 2.128 \\
\hline Inter-industry Spillovers (inter-s) & 11.87 & 0.777 & -0.089 & 2.327 \\
\hline \multicolumn{5}{|l|}{ Europe: 1467 observations } \\
\hline Employees (1) & 44,766 & 73,855 & 3.106 & 14.360 \\
\hline Sales (y) & 8.09 & 1.793 & -0.363 & 3.203 \\
\hline Capital expenditures (c) & 7.13 & 2.048 & -0.230 & 2.948 \\
\hline Operating profit (op) & 4.77 & 1.791 & -0.225 & 3.283 \\
\hline$R \& D(k)$ & 6.44 & 1.762 & 0.073 & 2.814 \\
\hline National Spillovers (ns) & 11.80 & 0.523 & -2.056 & 9.989 \\
\hline International Spillovers (is) & 12.19 & 0.575 & -1.789 & 8.745 \\
\hline Intra-industry Spillovers (intra-s) & 11.54 & 1.202 & -0.253 & 1.897 \\
\hline Inter-industry Spillovers (inter-s) & 11.87 & 0.777 & -0.089 & 2.327 \\
\hline \multicolumn{5}{|l|}{ Japan: 1030 observations } \\
\hline Employees (l) & 31,735 & 51,163 & 3.523 & 17.881 \\
\hline Sales (y) & 8.14 & 1.293 & 0.055 & 2.476 \\
\hline Capital expenditures (c) & 7.25 & 1.462 & 0.195 & 2.811 \\
\hline Operating profit (op) & 5.00 & 2.030 & 0.056 & 2.599 \\
\hline $\mathrm{R} \& \mathrm{D}(\mathrm{k})$ & 6.46 & 1.218 & 0.835 & 3.239 \\
\hline National Spillovers (ns) & 11.32 & 0.428 & -0.402 & 2.509 \\
\hline International Spillovers (is) & 12.80 & 0.325 & -1.221 & 5.889 \\
\hline Intra-industry Spillovers (intra-s) & 11.87 & 1.125 & -0.382 & 1.941 \\
\hline Inter-industry Spillovers (inter-s) & 12.15 & 0.675 & -0.118 & 1.751 \\
\hline \multicolumn{5}{|l|}{ USA: 1548 observations } \\
\hline Employees (1) & 33,349 & 55,853 & 3.317 & 16.348 \\
\hline Sales (y) & 7.87 & 1.777 & -0.118 & 3.023 \\
\hline Capital expenditures (c) & 6.75 & 1.814 & 0.100 & 2.681 \\
\hline Operating profit (op) & 5.10 & 2.022 & 0.022 & 2.792 \\
\hline$R \& D(k)$ & 6.81 & 1.357 & 0.543 & 2.948 \\
\hline National Spillovers (ns) & 12.05 & 0.368 & -1.474 & 7.590 \\
\hline International Spillovers (is) & 12.40 & 0.380 & -1.125 & 5.502 \\
\hline Intra-industry Spillovers (intra-s) & 12.17 & 0.997 & -0.954 & 3.024 \\
\hline Inter-industry Spillovers (inter-s) & 11.72 & 0.747 & 0.335 & 2.386 \\
\hline
\end{tabular}

We estimate the following equation:

$$
l=(y, c, o p, k, n s, \text { is, intra-s, inter-s })
$$

\section{Methodology and Empirical Results}

The number of employees is a discrete variable, and there are some large values that contribute substantially to the overdispersion. This feature makes it difficult to specify a model with a conditional mean and variance that captures the main characteristics of the data. For this reason, we estimate Equation (14) using Poisson and Negative Binomial models. In Table 2, we run the fixed-effect-Poisson (FE-POISS) estimates based on national versus international spillovers for all samples, while in Table 3 we show the fixed-effect Negative Binomial (FE-NBREG) for all samples. Akaike's information criterion 
(AIC) and Bayesian information criterion (BIC) procedures are used, see Table 4, to choose the best model. Because of the lower AIC and BIC, the FE-NBREG model is preferred. In this way, we can take into account the overdispersion in the data in a more opportune way. In particular, we include time and industry dummies in the estimation methods to control the impact of shocks and sector heterogeneity for the firms.

Table 2. Firm size estimates (all samples)—Fixed Effect Poisson (FE-POISS).

\begin{tabular}{|c|c|c|c|c|c|}
\hline \multicolumn{3}{|c|}{$\begin{array}{c}\text { Sample: } 838 \text { Firms X } 9 \text { Years-FE-POISS: } \\
\text { Ns/Is Spillovers }\end{array}$} & \multicolumn{3}{|c|}{$\begin{array}{l}\text { Sample: } 838 \text { Firms X } 9 \text { Years } \\
\text { FE-POISS: Intra-s/Inter-s Spillovers }\end{array}$} \\
\hline & Est. & s.e. ${ }^{a}$ & & Est. & s.e. ${ }^{a}$ \\
\hline Sales (y) & $0.52 * * *$ & $(0.001)$ & Sales (y) & $0.45^{* * *}$ & $(0.001)$ \\
\hline Capital expenditures (c) & $0.03^{* * *}$ & $(0.001)$ & Capital expenditures (c) & $0.01^{* * *}$ & $(0.001)$ \\
\hline Operating profit (op) & $-0.03^{* * *}$ & $(0.001)$ & Operating profit (op) & $-0.03^{* * *}$ & $(0.001)$ \\
\hline $\mathrm{R} \& \mathrm{D}(\mathrm{k})$ & $0.06^{* * *}$ & $(0.001)$ & $\mathrm{R} \& \mathrm{D}(\mathrm{k})$ & $0.04^{* * *}$ & $(0.001)$ \\
\hline National Spillovers (ns) & $0.06^{* * *}$ & $(0.001)$ & Intra-industry Spillovers (intra-s) & $0.12 * * *$ & $(0.002)$ \\
\hline International Spillovers (is) & $0.15 * * *$ & $(0.003)$ & Inter-industry Spillovers (inter-s) & $0.16^{* * *}$ & $(0.003)$ \\
\hline
\end{tabular}

a: *** Significance at the $1 \%$. Time and Industry dummies included.

Table 3. Firm size results (all samples)—Fixed Effect Negative Binomial (FE-NBREG).

\begin{tabular}{|c|c|c|c|c|c|}
\hline \multicolumn{3}{|c|}{$\begin{array}{c}\text { Sample: } 838 \text { Firms X } 9 \text { Years_FE-NBREG: } \\
\text { Ns/Is Spillovers }\end{array}$} & \multicolumn{3}{|c|}{$\begin{array}{c}\text { Sample: } 838 \text { Firms X } 9 \text { Years } \\
\text { FE-NBREG: Intra-s/Inter-s Spillovers }\end{array}$} \\
\hline & Est. & s.e. ${ }^{a}$ & & Est. & s.e. ${ }^{a}$ \\
\hline Sales (y) & $0.36 * * *$ & $(0.016)$ & Sales (y) & $0.39 * * *$ & $(0.015)$ \\
\hline Capital expenditures (c) & $0.04 * * *$ & $(0.007)$ & Capital expenditures (c) & $0.02 * * *$ & $(0.007)$ \\
\hline Operating profit (op) & $-0.03^{* * *}$ & $(0.004)$ & Operating profit (op) & $-0.03^{* * *}$ & $(0.004)$ \\
\hline $\mathrm{R} \& \mathrm{D}(\mathrm{k})$ & $0.12 * * *$ & $(0.010)$ & $\mathrm{R} \& \mathrm{D}(\mathrm{k})$ & $0.11^{* * *}$ & $(0.009)$ \\
\hline National Spillovers (ns) & 0.03 & $(0.026)$ & Intra-industry Spillovers (intra-s) & $0.05^{* * *}$ & $(0.018)$ \\
\hline International Spillovers (is) & $-0.22 * * *$ & $(0.042)$ & Inter-industry Spillovers (inter-s) & $-0.39 * * *$ & $(0.004)$ \\
\hline
\end{tabular}

a: *** Significance at the $1 \%$. Time and Industry dummies included.

Table 4. Comparison based on information criteria.

\begin{tabular}{ccc}
\hline & FE-POISS & FE-NBREG \\
\hline Nat/Int-Spillovers & & \\
\hline AIC & $1,662,009$ & 45,755 \\
BIC & $1,662,100$ & 45,858 \\
\hline \multicolumn{2}{c}{ Intra/Inter-Spillovers } & \\
\hline AIC & $1,342,567$ & 45,304 \\
BIC & $1,342,659$ & 45,407 \\
\hline
\end{tabular}

Hence, the other estimates are relative to the FE-NBREG model. In particular, Table 5 presents the findings by geographical perspective, and Table 6 shows the results using an intra/inter-industry perspective. We can observe that the output represents the most relevant determinant of firms' sizes with a significant positive effect, as expected. The effect of operating profit is negative; this leads to higher wages, and to lower firm sizes, as suggested in the empirical literature [41].

From the empirical findings, we observe that the compensation effect can be higher than the destruction one: Indeed, R\&D activity produces a positive impact on firms' sizes. As far as the knowledge spillovers are concerned, international components have a negative effect on firms' sizes for American firms and a positive effect for European ones, while national spillover components produce a positive impact on firms' sizes in Japan. These findings could be explained by the higher absorptive capacity of American firms to improved productivity and finally, to the decrease in firms' sizes. The reverse idea could be applied to Japan and Europe which have lower absorptive capacities. 
Table 5. Firm size estimates by geographical area-FE-NBREG.

\begin{tabular}{ccccccc}
\hline & \multicolumn{2}{c}{ Europe: 316 Firms } & \multicolumn{2}{c}{ Japan: 232 Firms } & \multicolumn{2}{c}{ USA: 290 Firms } \\
\hline & Est. & s.e. $^{\text {a }}$ & Est. & s.e. $^{\text {a }}$ & Est. & s.e. $^{\text {a }}$ \\
\hline Sales (y) & $0.45^{* * *}$ & $(0.020)$ & $0.26^{* * *}$ & $(0.053)$ & $0.37^{* * *}$ & $(0.029)$ \\
Capital expenditures (c) & 0.01 & $(0.010)$ & 0.02 & $(0.022)$ & $0.03^{* *}$ & $(0.013)$ \\
Operating profit (op) & $-0.03^{* * *}$ & $(0.006)$ & $-0.02^{*}$ & $(0.012)$ & $-0.03^{* * *}$ & $(0.006)$ \\
R\&D (k) & $0.10^{* * *}$ & $(0.009)$ & $0.13^{* * *}$ & $(0.041)$ & $0.27^{* * *}$ & $(0.023)$ \\
National Spillovers (ns) & -0.01 & $(0.028)$ & $0.21^{*}$ & $(0.117)$ & 0.04 & $(0.049)$ \\
International Spillovers (is) & $0.11^{* *}$ & $(0.057)$ & -0.07 & $(0.146)$ & $-0.56^{* * *}$ & $(0.064)$ \\
\hline
\end{tabular}

${ }^{a}: * * * * *,{ }^{*}$ Coefficient significant at the $1 \%, 5 \%, 10 \%$. Time and industry dummies included.

Table 6. Firm size results due to intra-s/inter-s spillovers-FE-NBREG.

\begin{tabular}{ccccccc}
\hline & \multicolumn{2}{c}{ Europe: 316 Firms } & \multicolumn{2}{c}{ Japan: 232 Firms } & \multicolumn{2}{c}{ USA: 290 US Firms } \\
\hline & Est. & s.e. $^{\text {a }}$ & Est. & s.e. $^{\text {a }}$ & Est. & s.e. $^{\text {a }}$ \\
\hline Sales (y) & $0.44^{* * *}$ & $(0.020)$ & $0.23^{* * *}$ & $(0.055)$ & $0.37^{* * *}$ & $(0.029)$ \\
Capital expenditures (c) & 0.01 & $(0.010)$ & 0.02 & $(0.023)$ & 0.02 & $(0.013)$ \\
Operating profit (op) & $-0.03^{* * *}$ & $(0.006)$ & -0.01 & $(0.011)$ & $-0.02^{* * *}$ & $(0.005)$ \\
R\&D (k) & $0.09^{* * *}$ & $(0.009)$ & $0.12^{* * *}$ & $(0.042)$ & $0.24^{* * *}$ & $(0.023)$ \\
Intra-industry Spillovers (intra-s) & $0.14^{* * *}$ & $(0.023)$ & -0.03 & $(0.107)$ & -0.04 & $(0.032)$ \\
Inter-industry Spillovers (inter-s) & -0.10 & $(0.062)$ & -0.18 & $(0.187)$ & $-0.59^{* * *}$ & $(0.063)$ \\
\hline
\end{tabular}

${ }^{a}:{ }^{* * *}$ Significance at the $1 \%$. Time and Industry dummies included.

Moreover, in the same vein, inter-industry externalities have a negative effect on firms' sizes for American firms, and intra-industry spillovers have a positive impact in Europe.

The results demonstrate the key role that competitive firms have with regard to the potential to help the economies to sustain firms' sizes in terms of employment in crucial periods of time, such as during a worldwide economic crisis. The novelty of this analysis for policymakers' industrial strategy is to outline not only the relevant impact of their own innovation [31], but also the existence of a complex structure for the transmission of external innovation through knowledge spillovers. We cannot distinguish between process and product innovation because of the lack of available data. Thus, future research could examine, in depth, this important aspect of firms' industrial organization.

\section{Conclusions and Policy Implications}

The paper explores the interaction between R\&D activity, spillovers, and firms' sizes in terms of employment. The analysis is based on 879 firms from 2002 to 2010 in Europe, Japan, and the USA. The findings outline the significant role of spillover effects on firms' sizes.

This paper confirms both the impact of the internal effects of innovation on firms' sizes, and the external effects due to technological spillovers. For this reason, industrial policy that favors these industrial mechanisms should be supported.

Indeed, adequate policy responses could become important instruments to sustain the effects of innovation on firms' sizes. Firstly, skill levels are closely related to inequality because technological change increases the demand for skilled employment, so it seems essential to invest in education [42].

Secondly, fiscal measures should encourage investments in R\&D to obtain the competencies relevant for full competitiveness in the long-run, as discussed in Peneder [43].

Finally, policymakers are likely to face some challenges due to the development of labor markets and the increasing flexible work structure, as requested by the markets.

These industrial strategies towards innovation are important in terms of sustainability, because on the one hand, firms can minimize the costs in such a way that the production is as efficient as possible, and on the other hand, the sustainable innovation allows them to achieve more production opportunities for future generations. 
However, the research should be further analyzed. Indeed, we cannot distinguish between process and product innovation impact on firms' sizes. Thus, we could not analyze the extent to which our results are robust with respect to previous technological taxonomy. Moreover, with a wider scope, we could analyze what happens after crises.

Author Contributions: Formal analysis, C.P.V.; Investigation; Methodology; Software, L.A.

Funding: The research received no external funding.

Conflicts of Interest: The authors declare no conflict of interest.

\section{References}

1. Leoncini, R.; Marzucchi, A.; Montresor, S.; Rentocchini, F.; Rizzo, U. 'Better late than never': The interplay between green technology and age for firm growth. Small Bus. Econ. 2017. [CrossRef]

2. Vivarelli, M. Technology, employment and skills: An interpretative framework. Eurasian Bus. Rev. 2013, 3, 66-89.

3. Vivarelli, M. Innovation, employment and skills in advanced and developing countries: A survey of economic literature. J. Econ. Issues 2014, 48, 123-154. [CrossRef]

4. Pezzey, J. Sustainability constraints versus optimality versus intertemporal concern, and axioms versus data. Land Econ. 1997, 73, 448-466. [CrossRef]

5. Cozzolino, A.; Verona, G.; Rothaermel, F.T. Unpacking the Disruption Process: New Technology, Business Models, and Incumbent Adaptation. J. Manag. Stud. 2018, 55, 1166-1202. [CrossRef]

6. Brynjolfsson, E.; McAfee, A. Race against the Machine: How the Digital Revolution Is Accelerating Innovation, Driving Productivity, and Irreversibly Transforming Employment and the Economy; Digital Frontier Press: Lexington, MA, USA, 2011.

7. Brynjolfsson, E.; McAfee, A. The Second Machine Age: Work, Progress, and Prosperity in a Time of Brilliant Technologies; W. W. Norton: New York, NY, USA, 2014.

8. Aldieri, L.; Carlucci, F.; Cirà, A.; Ioppolo, G. Is green innovation an opportunity or a threat to employment? An empirical analysis of three main industrialized areas: The USA, Japan and Europe. J. Clean. Prod. 2019. [CrossRef]

9. Erdil, E.; Çetin, D. Intra-OIZ and Intra-Industry Knowledge Spillovers in Ankara: A Spatial Econometric Analysis. Efil J. Econ. Res. 2018, 1, 8-32.

10. Aldieri, L.; Vinci, C.P. Green Economy and Sustainable Development: The economic Impact of Innovation on Employment. Sustainability 2018, 10, 3541. [CrossRef]

11. Aldieri, L.; Kotsemir, M.; Vinci, C.P. The Impact of environmental innovations on job-creation process: An empirical investigation for Russian regions. Environ. Econ. Policy Stud. 2018. [CrossRef]

12. Grafström, J. International knowledge spillovers in the wind power industry: Evidence from the European Union. Econ. Innov. New Technol. 2018, 27, 205-224. [CrossRef]

13. Freeman, R.B. Employment and Earnings of Disadvantaged Young Men in a Labour Shortage Economy (No. w3444); National Bureau of Economic Research: Cambridge, MA, USA, 1990.

14. Chennells, L.; Van Reenen, J. Technical change and the structure of employment and wages: A survey of the microeconometric evidence. In Productivity, Inequality and the Digital Economy; MIT Press: Cambridge, MA, USA, 2002; pp. 175-223.

15. Marin, G.; Mazzanti, M. The evolution of environmental and labour productivity dynamics. J. Evol. Econ. 2013, 23, 357-399. [CrossRef]

16. Bogliacino, F.; Piva, M.; Vivarelli, M. R\&D and employment: An application of the LSDVC estimator using European microdata. Econ. Lett. 2012, 116, 56-59.

17. Blanchflower, D.G.; Burgess, S.M. New Technology and Jobs: Comparative Evidence from a Two Country Study. Econ. Innov. New Technol. 1998, 5, 109-138. [CrossRef]

18. Brouwer, E.; Kleinknecht, A.; Reijnen, J.O. Employment growth and innovation at the firm level. J. Evol. Econ. 1993, 3, 153-159. [CrossRef]

19. Zimmerman, M.A. Psychological empowerment: Issues and illustrations. Am. J. Community Psychol. 1995, 23, 581-599. [CrossRef] 
20. Peters, B. Employment Effects of Different Innovation Activities: Microeconometric Evidence (No. 04-73); ZEW Discussion Papers; Zentrum für Europäische Wirtschaftsforschung: Mannheim, Germany, 2005.

21. Jaumandreu, J. Does innovation spur employment? A firm-level analysis using Spanish CIS data. Univ. Carlos III Madr. 2003, 17, 813-839.

22. Coad, A.; Rao, R. The firm-level employment effects of innovations in high-tech US manufacturing industries. J. Evol. Econ. 2011, 21, 255-283. [CrossRef]

23. Askenazy, P. Innovative workplace practices and occupational injuries and illnesses in the United States. Econ. Ind. Democr. 2001, 22, 485-516. [CrossRef]

24. Harrison, R.; Jaumandreu, J.; Mairesse, J.; Peters, B. Does innovations stimulate employment? A firm-level analysis using comparable microdata from four European countries. Int. J. Ind. Organ. 2014, 35, $29-43$. [CrossRef]

25. Lachenmaier, S.; Rottmann, H. Effects of innovation on employment: A dynamic panel analysis. Int. J. Ind. Organ. 2011, 29, 210-220. [CrossRef]

26. Piva, M.; Vivarelli, M. Technological change and employment: Some micro evidence from Italy. Appl. Econ. Lett. 2004, 11, 373-376. [CrossRef]

27. Piva, M.; Vivarelli, M. Innovation and employment: Evidence from Italian microdata. J. Econ. 2005, 86, 65-83. [CrossRef]

28. Evangelista, R.; Vezzani, A. The impact of technological and organizational innovations on employment in European firms. Ind. Corp. Chang. 2012, 21, 871-889. [CrossRef]

29. Van Reenen, J. Employment and technological innovation: Evidence from UK manufacturing firms. J. Labour Econ. 1997, 15, 255-284. [CrossRef]

30. Smolny, W. Innovations, prices and employment: A theoretical model and an empirical application for West German manufacturing firms. J. Ind. Econ. 1998, 46, 359-381. [CrossRef]

31. Ciriaci, D.; Moncada-Paternò-Castello, P.; Vogt, P. Innovation and Job creation: A sustainable relation? Eurasian Bus. Rev. 2016, 6, 189-213. [CrossRef]

32. Mitra, A.; Jha, A. Innovation and employment: A firm level study of Indian industries. Eurasian Bus. Rev. 2015, 5, 45-71. [CrossRef]

33. Aguilar-Fernandez, M.E.; Otegi-Olaso, J.R. Firm Size and the Business Model for Sustainable Innovation. Available online: https:/www.researchgate.net/publication/329655924_Firm_Size_and_the_Business_Model_ for_Sustainable_Innovation (accessed on 15 May 2019).

34. Chen, T.; Huang, G.; Olanipekun, A.O. Simulating the Evolution Mechanism of Inner Innovation in Large-Scale Construction Enterprise with an Improved NK Model. Available online: https://eprints.qut.edu.au/123447/ (accessed on 15 May 2019).

35. Melane-Lavado, A.; Alvarez-Herranz, A. Different Ways to Access Knowledge for Sustainability-Oriented Innovation. The Effect of Foreign Direct Investment. Available online: https://www.researchgate.net/ publication/328949499_Different_Ways_to_Access_Knowledge_for_Sustainability-Oriented_Innovation_ The_Effect_of_Foreign_Direct_Investment (accessed on 15 May 2019).

36. Garcia, A.; Jaumandreu, J.; Rodriguez, C. Innovation and Jobs: Evidence from Manufacturing Firms; MPRA Working Paper No. 1204; University Library of Munich: München, Germany, 2004.

37. European Commission. The 2000-2010 EU Industrial RED Investment Scoreboard; JRC Scientific and Technical Research Series; European Commission: Brussels, Belgium, 2011.

38. OECD. REGPAT Database; OECD: Paris, France, 2013.

39. Maraut, S.; Dernis, H.; Webb, C.; Spiezia, V.; Guellec, D. The OECD REGPAT Database: A Presentation; STI Working Paper 2008/2; OECD: Paris, France, 2008.

40. Jaffe, A.B. Technological opportunity and spillovers of R\&D: Evidence from firms' patents, profits and market value. Am. Econ. Rev. 1986, 76, 984-1001.

41. Bogliacino, F. Innovation and Employment: A firm level analysis with European R\&D Scoreboard data. EconomiA 2010, 15, 141-154. 
42. Goldin, C.; Katz, L.F. The Race between Education and Technology; Harvard University Press: Harvard, MA, USA, 2008.

43. Peneder, M. Sectoral Growth Drivers and Competitiveness in the European Union; Background Studies to the Competitiveness Report 2008; European Commission, DG Enterprise and Industry: Brussels, Belgium, 2009. 